Michael METZELTIN

Institutul de Romanistică din Viena

\title{
FORMELE UNIRII ÎN GEOPOLITICA EUROPEANĂ ${ }^{1}$
}

\section{O ocazie a rememorărilor}

Acum o sută de ani se sfîrșea un război teribil, Marele Război, cel mai rău de la Războiul de treizeci de ani (1618-1648), pentru prima oară de dimensiuni mondiale și prin recurgerea masivă la noile tehnologii. Este o aniversare care se pretează la rememorarea, între altele, a consecințelor geopolitice ale Primului Război Mondial.

Din punctul de vedere al geografiei politice, Conferința de pace de la Paris (1919-1920) și tratatele de pace încheiate între 1919 și 1923 (Versailles privitor la Germania, Saint-Germain-en Laye privitor la Austria, Neuilly privitor la Bulgaria, Trianon privitor la Ungaria, Paris privitor la România, Rapallo privitor la Italia și Yugoslavia, Lausanne privitor la Turcia) stabilesc dezmembrări, formarea de noi state și unificări:

- imperiile austro-ungar, german, rus și otoman sunt dezmembrate;

- se formează noi state naționale (Finlanda 1917, Estonia 1918, Letonia 1918, Lituania 1918, Polonia 1918, Ungaria 1918, Turcia 1923);

- $\quad$ se nasc noi uniuni federative (Cehoslovacia 1918, Yugoslavia / Regatul Sârbilor, Croaților și Slovenilor 1918);

- se produc unificări și reatașări: Alsacia și Lorena (restituite Franței), Trentin, Tirol de Sud, Marche Julienne / Küstenland și Zara (atribuite/reatașate Italiei) și Transilvania, Banatul, Bucovina și Basarabia (ale căror Consilii regionale respective proclamă / decid reatașarea lor la Regatul României).

Una din principalele surse de inspirație ale acestor dezmembrări, regrupări de populații și formări de noi state a fost (și continuă să fie) programul unui tratat de pace pe care președintele Statelor Unite, Woodrow Wilson, îl prezenta la 8 ianuarie 1918 Congresului și în care se poate găsi schițată ideea dreptului la autodeterminare a popoarelor, dar încă destul de vagă și parțială și, în fapt, limitată la teritorii ale imperiilor dezmembrate și la anumite populații, așa cum lasă să pară formulările următoare:

\footnotetext{
${ }^{1}$ Lucrarea a fost susținută în plenul conferinței Lexic comun / Lexic specializat. Limba și cultura română în context național și european: evaluări și perspective la Centenarul Unirii, Galați, 26-27 octombrie 2018.
} 
„IX. A readjustment of the frontiers of Italy should be effected along clearly recognizable lines of nationality.

$X$. The peoples of Austria-Hungary, whose place among the nations we wish to see safeguarded and assured, should be accorded the freest opportunity to autonomous development.

XI. Rumania, Serbia, and Montenegro should be evacuated; occupied territories restored; Serbia accorded free and secure access to the sea; and the relations of the several Balkan states to one another determined by friendly counsel along historically established lines of allegiance and nationality; and international guarantees of the political and economic independence and territorial integrity of the several Balkan states should be entered into.

XII. The Turkish portion of the present Ottoman Empire should be assured a secure sovereignty, but the other nationalities which are now under Turkish rule should be assured an undoubted security of life and an absolutely unmolested opportunity of autonomous development, and the Dardanelles should be permanently opened as a free passage to the ships and commerce of all nations under international guarantees."

"An evident principle runs through the whole program I have outlined. It is the principle of justice to all peoples and nationalities, and their right to live on equal terms of liberty and safety with one another, whether they be strong or weak.

Unless this principle be made its foundation no part of the structure of international justice can stand."

(https://wwi.lib.byu.edu/index.php/President_Wilson\%27s_Fourteen_Points; 23.08.2018)

(https://fr.wikipedia.org/wiki/Quatorze_points_de_Wilson; 23.08.2018)

În realitate, textul vorbește mai ales despre hotarele naționale și despre dezvoltarea autonomă. Dar deja în 1869 Dimitrie Bolintineanu afirma în lucrarea sa Cartea poporului român. Cugetări filosofice și politice în raport cu starea actuală a României că „Cel mai prețios drept al unei națiuni este dreptul ei de a se guverna precum ea voiește” (Dimitrie Bolintineanu, Opere, XII, București, Minerva, 1992, 339). Și ideea dreptului popoarelor de a dispune de ele însele circula chiar în timpul Marelui război, spre exemplu în România (Dorina N. Rusu, Cronica lumii românești 1914-1920, I, București, Academia Română, 2018, 375).

Or, în mod fundamental, un stat constă dintr-o regrupare, o uniune de persoane stabilite pe un anumit teritoriu și trăind sub o anumită legislație comună, eventual cu o cultură istoric comună. Un context de mari perturbări statale ca cel creat de Marele Război, care a schimbat atâtea frontiere, care a provocat atâtea migrații, care a forțat atâtea uniformizări, pune în evidență complexitatea istorică a conceptului politic de unire, care decurge din ideea de autodeterminare națională. În acest context, nu trebuie să se uite că înseși 
statele constituite deja, ca Marea Britanie, Franța și Spania, rezultă din unificarea treptată a mai multor state mici.

\section{Ce se poate înțelege prin unire?}

Ideea operației de 'a pune împreună, de a grupa elemente' poate fi exprimată în franceză prin verbul tranzitiv unir, verbul reflexiv s'unir, verbele factitive unifier și uniformiser (cu conotația 'a face ca elementele componente să devină asemănătoare') și prin substantivele abstracte union, unification și uniformisation. Pentru a exprima rezultatul acestei operații, franceza dispune de adjectivele uni, uniforme, unitaire și de substantivele abstracte union (cu o conotație de staticitate), unité, uniformité. Pentru aceleași concepte, se regăsesc, spre exemplu, în română verbele a uni, a se uni, a unifica, a uniformiza, substantivele unire, uniune, unificare, unitate, uniformitate și adjectivele unit, uniform, unitar și în germană lexemele einigen, vereinen, vereinigen ('a uni', 'a unifica'), sich vereinigen (și de asemenea sich zusammenschließen, cu imaginea de 'fermer ensemble'), vereinheitlichen ('a uniformiza'), Vereinigung, Union, dar și Zusammenschluss ('uniune'), vereint ('unit'), vereinheitlicht ('uniform') și einheitlich ('unitar'). Toate aceste expresii trimit la numeralul fundamental unu care le atribuie ca nucleu al semnificației ideea 'care nu are părți, nu poate fi divizat, nu variază, omogen', idee care este la baza concepției constituționale a statului francez (Constituția din 1791, Titre II, Art.1: „Regatul este unul și undivizibil"; Constituția din 1793, Art.1: "Republica franceză este una și indivizibilă."; Constituția din 1958, Art. 2: „Franța este o republică indivizibilă, laică, democratică și socială.").

Concepția posibilității existenței unei anume acțiuni sau a unei anume stări implică, în general, și posibilitatea contrariului său, a antonimelor sale; se poate dezuni, diviza, dezmembra (fr. désunir, diviser, démembrer) creând astfel dezuniri, divizări, dezmembrări (fr. des désunions, des divisions, des démembrements). Nucleul de bază al acestor antonime este ideea de divers, care se poate defini 'care prezintă trăsături variate' (DEX online s.v. divers), 'qui présente plusieurs aspects, plusieurs caractères différents, simultanément ou successivement', 'qui présentent des différences intrinsèques et qualitatives, en parlant de choses que l'on compare' (Petit Robert, s.v. divers).

Dacă se pleacă de la ideea că unirile sunt în general procese, pentru a înțelege din punct de vedere cognitiv formarea și funcționarea uniunilor politice care au existat sau există în mod real, trebuie să se explice predicatul de bază 'a uni' cu actanții săi și elementele sale circumstanțiale:

Cine este cel care (A subiect) - unește - pe cine/ ce (B; destinatar beneficiar) împotriva cui (C; opozant, antagonist prejudiciat) - unde - când - prin ce mijloace - pe ce baze - cu ce scop?

A fost B consultat și este de acord cu acțiunea? 
De ce vrea C să împiedice unirea?

Care este rezultatul?

Diferiții factori se pot concretiza în mai multe feluri, spre exemplu:

Subiectul A: un rege, un general, un guvern, o dinastie

Destinatarul B: oameni, popoare; el n-a fost consultat, se face un referendum

Opozantul C: un stăpân feudal, un suzeran, un stat protector, un hegemon

Localizarea: anumite teritorii

Temporalitatea: anumite segmente de timp apreciate a fi favorabile

Mijloace: o intervenție militară, alianțe, tratate

Motivații: exploaterea abuzivă, necesitatea într-ajutorării, necesitatea resurselor, legea celui mai puternic

Finalitatea: dorința de independență față de străin, formarea unei națiuni, dorința de hegemonie (hybris)

Rezultatul: independența, asuprirea, un stat federal, un stat centralizat.

Astfel, în funcție de rolul mai mult sau mai puțin important al acestor factori, sunt posibile mai multe tipuri de uniuni politice. Spre exemplu, crearea Elveției și a Țărilor de Jos are ca bază opoziția față de asuprirea unui hegemon considerat ca străin.

Confederația Elvețiană își are originea în opoziția față de grelele contribuții pe care locuitorii văilor înalte ale Lacului celor Patru Cantoane (Vierwaldstättersee) le datorau Habsburgilor, considerați ca un hegemon străin. Astfel, de-a lungul secolelor XIII și XIV, oamenii liberi din Uri, din Schwytz și din Nidwald, cele trei cantoane primitive, încheie pacte de alianță juridică și de apărare pe termen nelimitat, adică pacte de într-ajutorare împotriva țărilor terțe (Carta federală din 1291, pactul din Brunnen din 1315). Carta federală din 1291 stabilea între altele:

„Au nom du Seigneur, amen. C'est accomplir une action honorable et profitable au bien public que de confirmer, selon les formes consacrées, les mesures prises en vue de la sécurité et de la paix.- Que chacun sache donc que, considérant la malice des temps et pour être mieux à même de défendre et maintenir dans leur intégrité leurs vies et leurs biens, les gens de la vallée d'Uri, la Landsgemeinde de la vallée de Schwytz et celle des gens de la vallée inférieure d'Unterwald se sont engagés, sous serment pris en toute bonne foi, à se prêter les uns aux autres n'importe quels secours, appui et assistance, de tout leur pouvoir et de tous leurs efforts, sans ménager ni leurs vies ni leurs biens, dans leurs vallées et au dehors, contre celui et contre tous ceux qui, par n'importe quel acte hostile, attenteraient à leurs personnes ou à leurs biens (ou à un seul d'entre eux), les attaqueraient ou leur causeraient quelque dommage. Quoi qu'il arrive, chacune des communautés promet à l'autre d'accourir à son secours en cas de nécessité, à ses propres frais, et de l'aider autant qu'il le faudra pour résister à l'agression des méchants et imposer réparation du tort commis. - C'est ce que, par le geste consacré, ils ont juré 
d'observer en toute loyauté, renouvelant par le présent traité le texte de l'ancien pacte corroboré par un serment; sous réserve que chacun, selon sa condition personnelle, reste soumis, comme il convient, à son seigneur et lui rende les prestations auxquelles il est tenu."

(„În numele Domnului, amin. A confirma, după formele consacrate, măsurile luate în vederea securității și a păcii este a duce la bun sfârşit o acțiune onorabilă și profitabilă binelui public. - Ca fiecare să știe deci că, pe motivul răutății timpurilor și pentru a fi în stare să apere și să mențină în integritatea lor viețile lor și bunurile lor, oamenii din valea Uri, Landsgemeinde a văii Schwytz și cei din valea inferioară a Unterwald s-au angajat, sub jurământ făcut cu întreaga bunăcredință, a-și da orice ajutor unii altora, sprijin și asistență, cu toate puterile lor și cu toate eforturile lor, fără a-și menaja nici viețile, nici bunurile lor, în văile lor și în afară, împotriva aceluia și împotriva tuturor celor care, prin orice fel de act ostil, ar atenta la persoana lor sau la bunurile lor (sau la numai unul dintre ele), i-ar ataca sau le-ar cauza vreun prejudiciu. Orice s-ar întâmpla, fiecare dintre comunități promite celeilalte să sară în ajutorul ei în caz de necesitate, pe propriile sale cheltuieli, și să o ajute atât cât trebuie pentru a rezista agresiunii persoanelor rele și a impune repararea prejudiciului comis. - E ceea ce, prin gestul consacrat, au jurat să observe cu toată loialitatea, reînnoind, prin prezentul tratat, textul vechiului pact consfințit printr-un jurământ; sub rezerva că fiecare, conform condiției personale, rămâne supus, așa cum s-a convenit, stăpânului său și va restitui prestațiile (impozitele) pe care le datorează.") (https://fr.wikipedia.org/wiki/Pacte_f\%C3\%A9d\%C3\%A9ral, 17.08.2018)

Uniunea cantoanelor elvețiene este centrată pe participarea poporului.

Despotismul spaniol al lui Filip al II-lea cu politica sa ultracatolică și măsurile de represiune ale ducelui de Alba în cele șaptesprezece provincii ale Țărilor de Jos conduc la revolta, mai ales, a provinciilor protestante de sub conducerea lui Wilhelm de Orania pentru a-i alunga pe spanioli (Războiul de optzeci de ani, 1568-1648). Prin Unirea de la Utrecht din 1579 se unesc provinciile doritoare a se elibera de controlul spaniol; prin Actul de la Haye (Plakkaat van Verlatinghe) din 1581, redactat de Stările Generale ale Țărilor de Jos, șapte provincii (Olanda, Zeelanda, Gelderland, Overijssel, Frizia, Groningue și Utrecht), denunțând ofensele guvernului spaniol și declarându-1 decăzut din drepturi pe regele Spaniei, proclamă, de facto, independența Provinciilor Unite ale Țărilor de Jos/ Republiek der Zeven Verenigde Nederlanden). Această independență permite noii Uniuni, sub conducerea Stărilor generale constituite de delegațiile Stărilor provinciale, extraordinara sa expansiune comercială și colonială ca putere maritimă a sec. al XVII-lea. Ea este la originea Țărilor de Jos de astăzi. Unirea provinciilor olandeze este centrată pe delegații săi. 
În schimb, monarhia spaniolă este rezultatul unei grupări progresive și de lungă durată a teritoriilor, datorată războaielor de cucerire (recucerire a teritoriilor musulmane din Peninsula Iberică de către creștini, 722-1492), a unei anexări (Castilia și Navara, 1515), unor succesiuni dinastice (Castilia și León, 1230; Castilia și Seniorie de Biscaia, 1379) și unei uniri dinastice (Castilia și Aragon, 1479). Această uniune cunoaște până astăzi tendințe centrifuge care cer imperios alte adaptări. Uniunea monarhiei spaniole este centrată pe dinastie.

\section{Unificarea Italiei}

De la căderea Imperiului Roman şi până în sec. al XIX-lea, Italia a fost împărțită, politic, în mai multe state (Savoia, Genova, Milano, Veneția, Florența, Luca, Statele Pontificale, etc.), cu alcătuire schimbătoare, conduse de aristocrați (patricieni) locali (Genova, Veneția, Luca) sau de familii autohtone (Visconti, Gonzaga, Este, etc.) sau chiar stăpânite de dinastii străine (angevinii, aragonezii, Burbonii, Habsburgii). Aceste state au interese economice și hegemonice diferite, adesea contrare, care reușesc cu greutate să încurajeze o unificare politică. Dar grație avântului și înfloririi literelor și artelor în timpul Umanismului și al Renașterii, comune diferitelor state, Italia începe să fie percepută în interior și în străinătate ca o unitate culturală.

Reflecția asupra unității politice primește importante impulsuri de la acțiunile lui Napoleon în Italia; în 1802 el creează Republica italiană (cu Lombardia și Romagna), transformată în 1805 în Regatul Italiei. Intelectualii concep mai multe forme de unificare: unii se gândesc la o republică centralizată care pleacă de la popor (Giuseppe Mazzini), alții la o confederație (Vincenzo Gioberti, Cesare Balbo), sub conducerea papei sau a casei de Savoia. Problema care se pune este de a ști cine trece la acțiune și cum. Tentativele revoluționare legate de mișcarea carbonară eșuează (1817-1831). Cu timpul, devine clar că singurul stat cu o guvernare autohtonă și cu o oarecare putere militară care ar putea lua inițiativa este regatul Sardiniei; hegemonul de combătut: Austria. Un prim război de independență față de Austria, sub conducerea lui Carlo Alberto de Savoia și în alianță cu alte state italiene, de asemenea, eșuează (1848-1849). Sub conducerea lui Camillo Benso, conte de Cavour, președintele consiliului piemontez de la 1852 la 1859, regatul Sardiniei se modernizează, își mărește prestigiul participând la războiul Crimeei și găsește în Napoleon al III-lea un puternic aliat, ceea ce îi permite în 1859 să declanșeze al doilea război de independență împotriva Imperiului Habsburgic. Victoria piemontezilor și francezilor precipită evenimentele: regatul Sardiniei primește Lombardia (1859), dar trebuie să cedeze Franței ducatul de Savoia și comitatul de Nisa (1860); printr-un plebiscit, locuitorii Parmei, Modenei, ai Legațiunilor pontificale și ai Toscanei votează reunirea 
lor în regatul Sardiniei; Giuseppe Garibaldi cu cei o mie pune stăpânire pe Palermo și Napoli; armata sardă intră în Statele Pontificale și învinge trupele pontificale; locuitorii Siciliei și ai Neapolelui votează unirea lor cu regatul Sardiniei; locuitorii Statelor Pontificale (Umbria și Marche) votează unirea lor cu regatul Sardiniei.

Astfel, la 18 februarie 1861, se reunește primul parlament italian reprezentând Italia ca stat unitar, care la 17 martie dă naștere regatului Italiei proclamându-l pe Victor-Emanuel al II-lea de Sardinia „rege al Italiei prin grația lui Dumnezeu și voința națiunii". 17 martie este aniversarea Unității Italiei și din 2012 "Giornata dell'Unità nazionale, della Costituzione, dell'inno e della bandiera" (Legge Ordinaria n. 222 del 23/11/2012). („Ziua Unității Naționale, a Constituției, a imnului și a steagului")(http:// www.normattiva.it/urires/N2Ls?urn:nir:stato:legge:2012;222)

Stabilirea acestei aniversări sugerează că ideea de bază nu este unirea, nici unificarea, ci unitatea, ceea ce corespunde concepției primelor guvernări: pe baza unui sistem foarte centralizat, contrar federalismului și autonomiei locale, ele extind organizarea legislativă piemonteză asupra întregii peninsule. Unificarea va fi completată prin al treilea Război de Independență (Veneția, 1866), prin cucerirea Romei (1870) și prin participarea la Forțele Antantei în timpul Primului Război Mondial (Trentino, Tirolul de Sud, Küstenland / Marche Julienne, 1919-1920). Această ultimă unificare, cu caracter iredentist, este comemorată la 4 noiembrie prin "Giornata dell'Unità Nazionale e delle Forze Armate" (Ziua unității naționale și a Forțelor Armate). Datorată probabil eterogenității politice istorice a Statelor italiene, uniunea politică a Italiei se prezintă mai curând ca o unificare forțată, susținută de o elită politică, economică și militară a unui stat marginal, Piemontul, totuși votată prin plebiscit și nu lipsită de un anume iredentism.

\section{Unirile României}

În teritoriile românofone apar în Evul Mediu trei entități statale, pe care istoricii le numesc voievodate sau principate. În interiorul arcului Carpaților se dezvoltă din secolul al XII-lea voievodatul Transilvaniei. În cursul secolului al XIV-lea, sub conducerea elitelor venite din Transilvaniei, se constituie la sud și la est de Carpați voievodatele Valahiei și Moldovei, care se întindeau unul până la Dunăre și altul până la Prut și Nipru. E vorba de state autonome până în secolul al XIX-lea, dar aproape întotdeauna sub un regim de vasalitate față de regatul Ungariei sau față de Imperiul Otoman. Cu compromisul austroungar din 1867 Transilvania își pierde autonomia și este integrată în Ungaria Mare. 
Populațiile tradiționale ale celor trei principate au aceeași limbă, româna, și aceeași religie, ortodoxia. Contactele economice și politice sunt frecvente. Spre exemplu, prinţul valah Mihai Viteazul (1593-1601) a reuşit să devină atât prinț de Transilvania (1599), cât și de Moldova (1600), dar el nu unifică țările instituțional. Diferitele vasalități creează decalaje culturale între Valahia și Moldova, pe de o parte, și Transilvania, de altă parte. În principatele dunărene aristocrația boierilor este românească, religia oficială ortodoxă, limba bisericii și a administrației mai întâi slavona și apoi româna. În Transilvania, aristocrația este mai curând maghiară sau maghiarizată, religia oficială catolică sau protestantă, limba bisericii și a administrației latina, apoi maghiara sau germana; din secolul al XIV-lea, majoritatea valahă, care refuză să se convertească la catolicism sau să se maghiarizeze, este supusă unei opresiuni care s-a înăsprit după 1867. La aceste trei state s-a adăugat din 1849, ca un nou stat românofon, ducatul Bucovinei.

De la sfârșitul secolului al XVIII-lea, Imperiul Rus și Imperiul Otoman se confruntă pentru controlul principatelor dunărene, în care Sankt Petersbourg caută să-și impună influența tutelară. După războiul ruso-turc din 1828-1829, Paul Kiseleff, comandantul trupelor rusești din Moldova și Valahia, va fi în fapt, până în 1834, regentul celor două principate, pentru care face să se promulge două constituții în limba română (Regulamente organice) paralele în întregime. În 1853, otomanii respingând noile cereri rusești, războiul a izbucnit din nou, de data aceasta cu intervenția Franței, Regatului Unit și Regatului Sardiniei de partea Imperiului Otoman (Războiul Crimeei, 18531856); el se încheie prin înfrângerea Rusiei și prin tratatul de pace de la Paris din 1856. Articolul 24 din tratat stabilea că:

„Sa Majesté le Sultan promet de convoquer immédiatement, dans chacune des deux provinces, un Divan ad hoc, composé de manière à constituer la représentation la plus exacte des intérêts de toutes les classes de la société. Ces Divans seront appelés à exprimer les voeux des populations relativement à l'organisation définitive des Principautés."

(„Majestatea Sa, Sultanul, promite să convoace imediat, în fiecare din cele două privincii, câte un Divan ad hoc, în aşa fel alcătuit încât să constituie reprezentarea cea mai exactă a intereselor tuturor claselor societății. Aceste Divane vor fi chemate să exprime voința populației relativ la organizarea definitivă a Principatelor.")

(http://mjp.univ-perp.fr/traites/1856paris.htm; 20.08.2018)

Divanele s-au reunit anul următor și au exprimat dorințe identice: unirea într-un singur stat, garantarea autonomiei și a neutralității, o adunare reprezentativă, o guvernare constituțională, un suveran aparținînd unei dinastii străine. Dar puterile garante (Franța, Regatul Unit, Rusia, Sardinia, 
Austria, Prusia, Imperiul Otoman) au promulgat în 1858 „Convenția relativă la organizarea Principatelor Moldovei și Valahiei" (Convention relative à l'organisation des Principautés de Moldavie et de Valachie) stipulând că:

„Les Principautés de Moldavie et de Valachie, constituées désormais sous la dénomination de Principautés unies de Moldavie et de Valachie, demeurent placées sous la suzeraineté de Sa Majesté le Sultan." (Art. premier)

"Les pouvoirs publics seront confiés, dans chaque Principauté, à un Hospodar et à une Assemblée élective agissant dans les cas prévus par la présente Convention, avec le concours d'une Commission centrale commune aux deux Principautés." (Art. 3)

"L'Hospodar sera élu à vie par l'Assemblée." (Art. 10)

(„Principatele Moldovei și al Valahiei, organizate de acum înainte sub denumirea de Principatele unite ale Moldovei și Valahiei, rămân plasate sub suzeranitatea Majestății sale Sultanul," (art.1)

„Puterile publice vor fi încredințate, în fiecare Principat, unui Hospodar (domnitor/suveran) și unei Adunări elective activă în situațiile prevăzute prin prezenta Convenție, cu concursul unei Comisii centrale comună celor două Principate." (art.3)

"Hospodarul (domnitor/suveran) va fi ales pe viață de Adunare."(art.10)) (https:// bibliotheque-

numerique.diplomatie.gouv.fr/ark:/12148/bpt6k9770889z/f10.image.texteImage; 22.08.2018)

În 1859, Adunările, separat, aleg același Hospodar (Domnitor/suveran), colonelul Alexandru Ioan Cuza, și realizează prin acest fapt unirea personală a celor două principate. În decembrie 1861, Cuza proclamă unirea legală

„Românilor!

Unirea este îndeplinită.

Naționalitatea Română este întemeiată.

Alesul Vostru Vă dă astăzi o singură României.

..."

(http:/ / centenarulromaniei.ro/proclamarea-unirii-principatelor-romane-din-11decembrie-1861/; 20.08.2018)

În ianuarie 1862, guvernele separate demisionează, permițând astfel deschiderea la București a Parlamentului reunit al României, în fața căruia Cuza proclamă Unirea definitivă a Principatelor și Bucureștiul drept capitală a noului stat. Unirea statală este confirmată prin prima Constituție promulgată de noul principe suveran Carol I, în 1866; primul articol stabilește că ", Principatele Române unite constitue un singur stat indivizibil, sub numele de România." Cu ocazia războiului ruso-turc din 1877-1878, în care România luptă în mod victorios de partea Rusiei, Parlamentul declară independența 
(Kogălniceanu: „Suntem independenți; suntem națiune de sine stătătoare”, 9 mai 1877), recunoscută de Congresul de la Berlin din 1878. În martie 1881, Parlamentul votează transformarea României în regat, cu principele Carol I ca rege.

Cel puțin din sec. al XVII-lea, cum o mărturisește cronicarul și omul politic moldovean Miron Costin, românii de pe cele două versante ale Carpaților, din Moldova, din Muntenia și din Ungaria, sunt conștienți de originea și cultura lor comună, care îi diferențiază de popoarele învecinate. Această conștiință este întărită în sec. al XVIII-lea prin mișcarea latinofilă a Școlii Ardelene și se generalizează în sec. al XIX-lea, cum o demonstrează compoziția membrilor fondatori ai Academiei Române, unde între cei 21 de membri se găsesc opt transilvăneni, trei bucovineni și trei basarabeni. Unirea de la 1859 a lăsat să se întrevadă posibilitatea reunirii, într-o bună zi, a tuturor teritoriilor de origine românofonă. Carol I acționează cu tenacitate pentru modernizarea și recunoașterea internațională a României, dar aceste posibilități de mărire a țării sunt limitate de situația geopolitică a României, încercuită de imperii ostile, și prin legăturile sale dinastice cu casa imperială a Germaniei.

$\mathrm{Cu}$ ocazia declanșării Marelui Război, România va rămâne mai întâi neutră, dar presată și de Tripla Antantă și de Tripla Alianță (Puterile Centrale), în 1916 ea trebuie să se angajeze de o parte sau de cealaltă. Guvernul decide să intre în război de partea Antantei; la consiliul de Coroană din 27 august, regele Ferdinand I confirmă această decizie luând partea împotriva originii dinastice și pentru poporul român:

„Scormonind adânc în conștiința mea, am ajuns cu durere la concluzia că interesele României nu merg alături de cele ale Austro-Ungariei și, în consecință, cu cele ale Germaniei. A trebuit să impun inimii mele tăcerea; asta n-a fost ușor; cu sufletul torturat am luat hotărârea de a-mi face datoria față de poporul român, ale cărui destine le conduc."

(Dorina N. Rusu, Cronica lumii românești 1914-1920, I, București, Academia Română, 2018, 193)

Intenția principală nu este de a cuceri teritorii - regele Ferdinand confirmă pe 17 august 1917 că "Războiul nostru nu porni din dorința de cucerire" (ib. 427) -, ci de a redobândi posesia unui leagăn național, Transivania. În ciuda eforturilor eroice, în fața armamentului german mai modern, a multiplicării fronturilor, a abandonului trupelor ruse, a izolării geografice în raport cu alte țări ale Antantei, armata română trebuie să se replieze și guvernul acceptă o pace umilitoare care dezmembrează țara (tratatul de la București, 7 mai 1918). Regele nu o ratifică și la 31 octombrie 1918 România denunță tratatul și reia ostilitățile împotriva Imperiiilor 
centrale. Victoria aliaților reconfigurează harta politică a Europei și conduce la o serie de autodeterminări. În Basarabia, Sfatul Țării proclamă independența față de Rusia și votează unirea sa cu Regatul Romăniei (,,se unește cu mama sa România"; 18 martie 1918). În Bucovina, Consiliul Național Român votează unirea sa la 2 noiembrie 1918 („Constituanta hotărăște unirea Bucovinei integrale cu celelalte țări romănești într'un stat național independent”). În Transilvania, Mare Sfat Național trimite regelui Ferdinand la 1 Decembrie 1918, următoarea telegramă:

"Adunarea Națională a Românilor din Ardeal, Banat și Țară Ungurească, ținută în Alba-Iulia, glorioasa cetate a lui Mihaiu Viteazul, a decretat într'un elan de entuziasm fără margini, cu unanimitate, unirea teritoriilor sale cu Regatul României." (cf. Bogdan Bucur, Cartea de aur a Centenarului Marii Uniri, București, RAO, 2017; 100, 210)

Aceste uniri au fost confirmate prin tratatele de la Versailles, Saint-Germainen-Laye și Trianon (1919-1920).

Formarea României Mari din 1918 se prezintă ca o lentă regrupare național identitară autohtonă, de-a lungul celor două versante ale Carpaților, conștient dorită de o majoritate de intelectuali, de oameni politici și de populația românofonă, dar continuu împiedicată de învecinări interesate de controlul marilor căi de comunicare și de bogățiile regiunilor carpatice. Această lungă opoziție străină este cea care a făcut să se nască visul românilor, de atâtea ori repetat, de întregire a țărilor române într-o Românie Mare, cum se exprimă Eugen Lovinescu în ale sale Note de război (1919):

„Nu mai sunt Carpații...Au fost prea mult. De două milenii creasta lor sălbatică a dominat întreagă istorie a neamului nostru. Și în bine și în rău. Ne-a despărțit, înstrăinându-ne unii de alții, ne-a retezat fără milă în două: diejecta membra. Membre risipite, ce au străbătut prin toate vicisitudinile veacurilor, făurindu-și în tăcere visul unei uniri zădărnicite de acest spate de gigant ridicat tocmai în mijlocul Daciei străbune. Și totuși, în veacurile grele, Carpații ne-au fost și de mare ajutor. În văgăunile lor tainice s-a păstrat neștirbită rasa noastră, copleșită din toate părțile de pluhoaiele desfundate ale barbarilor hrăpăreți. În locul unui zid de despărțire, ei vor deveni astfel coloana vertebrală a unui corp bipartit, solid organizat în jurul lor." (Dorina N. Rusu, Cronica lumii românești 1914-1920, I, București, Academia Română, 2018, 193)

\section{De la Comunitatea economică la Unirea politică}

După al doilea război mondial, oamenii politici caută idei pentru a reconstrui economic și social Europa, pentru a evita un nou război, pentru a asigura o pace durabilă și a încuraja o integrare progresivă a Europei. În țările care se socotesc acum a fi "occidentale", și sub influența în creștere a Statelor Unite ale Americii, mai ales prin intermediul Agențiilor sale, este foarte 
prezentă ideea că trebuie să fie oprit expansionismul ideologic și militar sovietic și împiedicată renașterea unei Germanii puternice. Principiile directoare ar fi drepturile fundamentale ale omului, democrația (participarea cetățenilor), liberul schimb și statul de drept (puterile politice sunt de asemenea supuse Legii). Ca mijloace de a realiza toate aceste deziderate se au în vedere cooperări politice, economice și militare care recomandă indirect sau direct formarea uniunilor de state (cf. între alții Brendan Simms, Europe: The Struggle for Supremacy, 1453 - to the Present, London 2013, Chap. 7).

În 1948, șefii de stat din Regatul Unit, Belgia, Franța, Luxembourg și Țările de Jos semnează la Bruxelles un tratat de cooperare economică, socială, culturală și de apărare colectivă. (http://www.weu.int/Treaty.htm; 22.08.2018).

În declarația sa din 9 mai1950, Robert Schuman, ministrul Afacerilor externe din Franța, ia în considerare o "grupare a națiunilor europene" pe termen lung și propune "să plaseze ansamblul producției franco-germane de cărbune și oțel sub o Înaltă Autoritate comună, într-o organizație deschisă participării și altor țări din Europa." (htpps://www.robertschuman.eu/fr/declaration-du-9-mai-1950; 22.08.2018)

În 1951, plenipotențiarii din Republica Federală Germană, Belgia, Franța, Italia, Luxembourg și Țările de Jos semnează la Paris Traité instituant la Communauté Européenne du Charbon et de l'Acier (Tratatul de instituire a Comunității Europene a Cărbunelui și Oțelului; CECA), care va fi ratificat de toate parlamentele și va intra în vigoare în 1952. Comunitatea are ca misiune „să contribuie, în armonie cu economia generală a statelor membre și grație stabilirii unei piețe comune (...), la expansiunea economică, la creșterea ocupării forței de muncă și la creșterea nivelului de trai al statelor membre." (Articolul 2). Ea are o personalitate juridică (Art. 6), este reprezentată prin instituțiile sale (o Înaltă Autoritate, o Adunare Comună, un Consiliu Special al miniștrilor și o Curte de Justiție) (Art.7) și "beneficiază, pe teritoriul statelor membre, de imunitățile și privilegiile necesare pentru a-și îndeplini misiunea" (art.76). Tratatul se concentrează asupra dispozițiilor economice, sociale și financiare și asupra politicii comerciale. Orice stat european poate cere să adere la tratat (art.98).

Dacă eforturile de unire sau unificare ale elvețienilor, olandezilor, spaniolilor, ialienilor și românilor ajunseseră la formarea unui stat național, cu Comunitatea Europeană a Cărbunelui și Oțelului asistăm la crearea unei entități cu caracter statal (nu este o organizație, ci o comunitate, are o personalitate juridică și are instituții similare cu cele ale statelor naționale), care nu mai este națională, ci mai degrabă supranațională (membrii Înaltei Autorități sunt numiți de guvernele statelor membre; dar articolul 9 din 
tratat stabilește că: "Fiecare stat membru se angajează să respecte acest caracter supranațional și să nu încerce să-i influențeze pe membrii Înaltei Autorități în îndeplinirea sarcinilor lor"), formată dintr-un număr deschis de state naționale membre și trebuie să acorde Comunității imunități și privilegii. Statele Unite, care sunt totuși un stat național, sunt primele care recunosc CECA ca entitate independentă și stabilesc o delegație adecvată la Bruxelles (1952). Instituția CECA obligă să se regândească concepția despre suveranitate și identitatea statului național.

Tratatul este un succes. El este dezvoltat prin Tratatul de instituire a Comunității Economice Europene (CEE, 1957, ratificat de parlamente), prin Actul Unic European (care renunță la adjectivul Economic, AUE, 1986, ratificat de statele membre, referendum în Danemarca), prin Tratatul privind Uniunea Europeană (TUE sau Tratatul de la Maastricht, 1992, controlul conformității constituționale de către instanțele supreme) și conduce la Tratatul de la Lisabona (2007, ratificat de parlamente). Tratatul din 1957 reia în mod fundamental principiile CECA (printre altele, accentul pus pe libera circulație a mărfurilor, a persoanelor, a serviciilor și a capitalului). Actul Unic European internaționalizează Comunitatea prin adăugarea la text a titlului III "Dispoziții asupra cooperării europeane în domeniul politicii externe".(https:/ / eur-lex.europa.eu/legalcontent/FR/TXT/PDF/?uri=CELEX:11986U/TXT\&from=FR; 22.08.2018)

Prin Tratatul din 1992, Comunitatea este transformată într-o Uniune, care își stabilește obiectivele, printre altele, "să-şi afirme identitatea pe scena internațională, în special prin punerea în aplicare a unei politici externe și de securitate comune, inclusiv definirea viitoare a politicii de apărare comună, care ar putea conduce, în timp util, la o apărare comună"și "să consolideze protecția drepturilor și intereselor cetățenilor statelor membre prin stabilirea unei cetățenii a Uniunii " (titlul I, art. B). Pentru prima dată apare un titlu dedicat culturii (titlul IX, art. 128), care prevede:

"(1) Comunitatea contribuie la dezvoltarea culturilor statelor membre, în respectul diversității lor, națională și regională, punând în evidență moștenirea culturală comună.

(2) Acțiunea Comunității țintește să încurajeze cooperarea între statele membre și, dacă este necesar, să sprijine și să completeze acțiunile lor în următoarele domenii:

- îmbunătățirea cunoașterii și diseminării culturii și istoriei popoarelor din Europa,

- conservarea și protejarea patrimoniului cultural de importanță europeană " (https://eur-lex.europa.eu/legalcontent/EN/TXT/HTML/?uri=CELEX:11992M/TXT\&from=EN; 22.08.2018) 
Tratatul de la Lisabona reformulează aceste obiective în Preambul și în articolul 3, în timp ce la articolul 2 prezintă o listă confuză semantic a valorilor pe care este fondată Uniunea:

„Uniunea se întemeiază pe valorile respectării demnității umane, libertății, democrației, egalității, statului de drept, precum și pe respectarea drepturilor omului, inclusiv drepturile persoanelor care aparțin minorităților. Aceste valori sunt comune statelor membre într-o societate caracterizată prin pluralism, nediscriminare, toleranță, justiție, solidaritate și egalitate între femei și bărbați". (https:/ / eur-lex.europa.eu/resource.html?uri=cellar:2bf140bf-a3f8-4ab2-b506fd71826e6da6.0002.02/DOC_1\&format=PDF; 22.08.2018)

Autorii textului confundă principii și valori (demnitatea și egalitatea sunt principii incomensurabile, în timp ce libertatea și democrația sunt valori ce pot fi măsurate în grade). De altfel, așa-numitele valori nu sunt specifice pentru Uniunea Europeană.

Din punct de vedere numeric, Comunitatea / Uniunea se extinde treptat odată cu aderarea Regatului Unit, Irlandei și Danemarcei (1973), Greciei (1981), Spaniei și Portugaliei (1986), Austriei, Suediei și Finlandei (1995), Ciprului, Republicii Cehe, Estoniei, Ungariei, Letoniei, Lituaniei, Maltei, Poloniei, Slovaciei și Sloveniei (2004), Bulgariei și României (2007) și Croației (2013). Tratatele de aderare sunt ratificate de parlamente, în Austria și prin referendum. Extinderea masivă între 2004/2007 de la Vest spre Est este izbitoare. Se poate pune întrebarea în ce măsură toate țările implicate au contribuit în decursul secolelor la conceperea, crearea și dezvoltarea patrimoniului cultural european comun. De asemenea, se poate întreba ce au a face portughezii, de exemplu, cu letonii.

Am văzut că unirea cantoanelor elvețiene este centrată pe participarea oamenilor, unirea provinciilor olandeze, pe delegați și unirea monarhiei spaniole, pe dinastie. Unirea politică din Italia arată mai mult ca o unificare forțată, susținută de elita politică, economică și militară a unui stat marginal, Piemontul, dar totuși votată prin plebiscit. Formarea României Mari în 1918 se prezintă ca o lentă regrupare națională identitară, autohtonă, de-a lungul ambilor versanți ai Carpaților, în mod conștient dorită de o majoritate de intelectuali, politicieni și populație românofonă. Toate aceste țări au luptat pentru a întemeia state naționale suverane cu propria lor identitate istorică. Crearea Comunității Europene a Cărbunelui și Oțelului, care a dus la Tratatul de la Lisabona, impune cetățenilor statelor europene să reconceapă suveranitatea și identitatea națională, ceea ce poate fi derutant, deoarece textele nu propun o soluție clară, mai ales că articolul 
4.2. din Tratatul de la Lisabona stabilește că „Uniunea respectă egalitatea statelor membre în raport cu tratatele precum și identitatea lor națională".

Dacă se reia explicația cognitivă a predicatului de bază "a uni“, în cazul Uniunii Europene, cetățenii diferitelor state naționale ar trebui să se întrebe:

- Cine cu adevărat vrea ce fel de integrare? (economică?, socio-economică?, politică?, militară?)

- Dacă o majoritate (care?) dorește o integrarea politică, care ar fi pentru Europa diversității forma cea mai potrivită, o confederație de state sau un stat federal?

- Cine sunt, cu adevărat, beneficiarii?

- Care sunt beneficiile?

- Până la ce punct beneficiarii au aceleași idei despre pretinsele valori comune?

- În ce constă, cu adevărat, „moștenirea culturală, religioasă și umanistă a Europei“ (preambulul Tratatului de la Lisabona) și la ce se opune ea?

- La ce ar trebui să renunțe beneficiarii?

- Cui se opune Uniunea europeană? Dacă conducătorii săi cred că trebuie să intre în concurență cu marile puteri, cum ar fi Statele Unite, Rusia sau China, ei nu consideră că aceste puteri, independent de numele lor oficiale, sunt state naționale cu forță militară proprie și uită că, spre deosebire de statele membre ale unor țări ca Statele Unite sau Brazilia, statele europene au fiecare istorii culturale profunde și diverse. Din ce motiv, președintele Comisiei și președintele Consiliului European, care nu reprezintă niciun stat, participă la summiturile G7?

- Cine se opune geopolitic unei Uniuni Europene ca entitate de stat? În ce măsură Mackinder încă bântuie fanteziile anglo-saxone? (vezi George Friedman)

(https://www.freiewelt.net/reportage/ george-friedman-usa-gegendeutsch-russische-kooperation-10057006/; 23.08.2018)

- Cum să găsim un echilibru între o economie de piață pur matematizată cu un liber-schimb (comerț) necontrolat și o economie planificată și controlată de administrația centrală?

- Cum să găsim un echilibru între o uniformizare favorabilă modernizării și optimizării economiei și o diversitate favorabilă creativității?

- De ce Tratatul de la Lisabona a renunțat la deviza "In varietate concordia" / "Unitatea în diversitate"?

- În cele din urmă, cum să stabilim o a treia cale între Atlantism și Eurasianism? 
Un răspuns la aceste întrebări ar putea permite o discuție mai deschisă despre concepțiile posibile și realizabile ale dorinței de suveranitate și ale nevoii de identitate. Ar putea explica de ce oficialii britanici se tem să-și dizolve suveranitatea; ar (putea) explica disconfortul semnatarilor Declarației de la Paris din 2017 (https:/ / thetrueeurope.eu/ une-europe-en-laquelle-nous-pouvons-croire/, 08.23.2018); ar (putea) clarifica utilitatea stabilirii statelor naționale, națiunile având nevoie de o configurație statală care să garanteze o anumită stabilitate și o anumită participare a cetățenilor; ar (putea) învăța cum fie o economie planificată și controlată de administrația centrală, care permite statului să aloce resurse într-un mod parțial, fie un neoliberalism excesiv care să permită privatizarea resurselor comune și reducerea ființei umane numai la o forță de muncă, împiedică construirea unei societăți bazate pe binele comun și pe bucuria unei anumite bunăstări generalizate.

O experiență interesantă în acest context ar putea fi refacerea Tratatului de la Lisabona pe modelul Constituției Elveției, care a găsit și găsește încă un echilibru satisfăcător între uniformizarea federală și diversitatea cantonală.

\section{Forms of Union in European Geopolitics}

Abstract: If we look at the European history of the Middle Ages, we can see a slow process of concentration in the states that led in the $19^{\text {th }}$ and $20^{\text {th }}$ centuries in the formation of the national states. Several of them originate from a union of smaller state entities. The reasons for the union were different, often fighting an oppressive hegemon, but the result was generally a union of citizens who constitute the sovereign. Ever since the end of the Second World War, some hegemonic forces with a dubious legitimacy have been trying to overlap over the European states a suprastate union in which it is not clear who the sovereign is and who are the true beneficiaries. Based on an analytical model of the union concept, our paper outlines the issues of sovereignty and the distribution of the benefits fought by the national states and which the European Union must resolve.

Key words: European Community, geopolitics, sovereignty, Treaty of Lisbon, Union, European Union.

NOTĂ: Textul original în franceză a fost publicat în Analele Universităţii de Vest din Timișoara. Seria Stitințe Filologice, LVI/2018, 55-67.

Le mulțumesc Doamnelor conf. univ.dr. Doina Bejan și conf. univ. dr. Oana Cenac pentru traducerea textului în limba română. 